\title{
Hva styrer våre medisinske avgjørelser?
}

\author{
En kjedelig, regnfull dag på hytta zappet jeg mellom TV-kanalene og kom tilfeldigvis innom en amerikansk \\ variant av Hellstrøm rydder opp. Dette var ikke om dårlig drevne restauranter, men om hoteller som slet.
}

Jeg kom inn i programmet mot slutten der programleder og problemløser sier at han nå har snakket med alle og hørt eksempler på deres vanskeligheter den siste tiden. Han innkaller til et allmøte tidlig neste morgen, hvor de ansatte får en lapp der de skal besvare spørsmålet: «Hvem er viktigst for deg i ditt arbeid?»

Svarene ble raskt samlet inn og skrevet opp på en tavle. Resepsjonisten hadde resepsjonssjefen som viktigst, stuepikene hadde husøkonomen som viktigst, direktøren hadde styreleder som viktigst, osv. Det var i alt 14 forskjellige svar på spørsmålet. Deretter avdekket man en ny tavle der problemløseren hadde skrevet opp stikkord for 22 situasjoner som de ansatte tidligere i programmet hadde presentert som eksempler på sine problemer. $20 \mathrm{av}$ problemstillingene var merket med grønt, og problemløseren informerte om at disse helt sikkert ville vært håndtert annerledes og sannsynligvis løst - dersom de ansatte hadde riktig svar på spørsmålet de fikk da de kom. Ingen hadde svart riktig, ettersom den viktigste personen for alle som arbeider på et hotell selvfølgelig er gjesten.

Heretter fikk alle ansatte beskjed om å sende enhver oppgave gjennom et «hva er til gjestens beste»-filter når et problem oppsto. Om de ikke selv gjorde det, skulle enhver annen ansatt kunne løfte frem spørsmålet, og den ansvarlige måtte da i løpet av 24 timer skriftlig kort begrunne hvorfor han eller hun hadde valgt en løsning som avvek fra dette styringsspørsmålet.

\section{Til pasientens beste?}

På bordet foran meg lå dagens avis med nok en historie om hvor dårlig vi i norsk helsevesen noen ganger behandler våre pasienter. Denne dagen hadde en pasient sittet i kø på den lokale legevakten med skulderen ute av ledd, og da det ble hans tur, ble han satt i en drosje for å bli kjørt til den legevakten han bostedsmessig tilhørte. Tror vi at denne løsningen ble valgt fordi det var til pasientens beste?

De fleste av oss har vel også gremmet oss når vi har lest om de pasientene som var klarert, ja endog lå i narkose på operasjonsbenken for store livsviktige operasjoner, og som ble vekket opp fordi de lå i feil bygning i Oslo universitetssykehus. At dette også medførte dødsfall i ventetiden, før de ble mottatt der retningslinjene nå sa at de skulle opereres, gjorde hendelsene ikke bare medisinsk uetiske, men ekstremt tragiske. Hvordan kunne man la dette skje? Hvilken mulighet hadde de som var i operasjonsstuen til å protestere mot det som skjedde?

Tenk om helsepersonell hadde hatt en stående ordre om at hvem som helst som erfarte slike situasjoner, kunne presentere spørsmålet: «Er valget vi nå gjør, til beste for pasienten?» Og tenk om den ansvarlige, i lys av dette spørsmålet, måtte forsvare sitt valg skriftlig i løpet av de neste 24 timene, $\mathrm{i}$ forhold til hva som var pasientens beste.

Jeg skulle ønske at vi ble gitt lov og retningslinjer til å praktisere behandling og sykepleie etter de idealene som fagene våre faktisk bygger på. Det skulle vært helt unødvendig at pasienter forteller at de var så «heldige» som brakk lårhalsen nå, fordi de da ble inkludert i et prosjekt på sykehuset slik at de ville bli operert i løpet av 24 timer.

Hvem har bestemt at det er «medisinsk forsvarlig» å la pasienter ligge på gangen, stinn av smertestillende, $i$ tre-fire dager med brukket lårhals? Er det slik vi selv ønsker å bli behandlet i samme situasjon?

Mitt ønske er at vi skal kunne styre våre medisinske avgjørelser etter hva som er til pasientens beste - alltid - ikke bare fordi man har et prosjekt på avdelingen. Men dessverre praktiseres ikke en slik «beste praksis» på alle sykehus i Norge anno 2014.

Man kan sikkert vise til at man har fulgt de gjeldende retningslinjene, men det er ikke sikkert at de gir alle svar og alltid tilfredsstiller det overordnede spørsmålet om hva som er best for pasienten.

\section{Feilslått styring}

Når svaksynte, engstelige og pleietrengende i hjemmet må forholdes seg til 20-25 forskjellige mennesker fra hjemmesykepleien, forstår vi alle at denne organiseringen ikke er blitt styrt av hva som er til pasientens beste.

På meg kan det virke som om det er de mange administrative og økonomiske føringer som styrer arbeidsplassene i Norge nå. Dette gjelder ikke bare medisin og helse. Det er blitt fortalt at det i Oslo er

\section{Lars Kolsrud \\ Lars Kolsrud (f. 1950) er overlege ved Toppidrettssenteret i Oslo.}

\section{PUBLISERT I BLOGGEN}

$$
\text { (b) 14.3. } 2014
$$

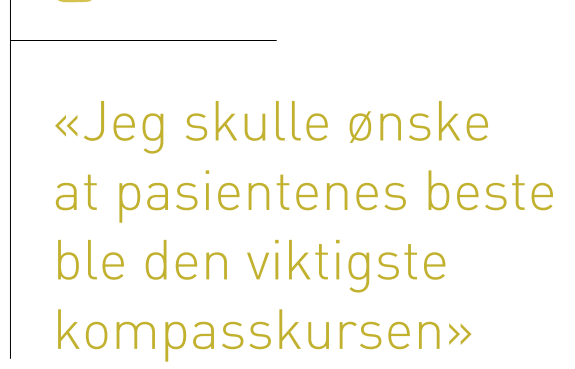

mest politi på vakt på tirsdager. Er det på tirsdager innbyggerne $\mathrm{i}$ hovedstaden har mest behov for sitt politi? Jeg vet ikke om noe spesielt som skjer tirsdager - annet enn at Se \& Hør kommer i butikkene - men trenger vi størst politibemanning på grunn av det?

Man kan sikkert med rette si at jeg ikke har kunnskap om de styringsmodellene som gjør dette så vanskelig, men tenk om det er noe feil med styringsmodellene? Dersom pasientens beste ikke er det viktigste, må vel modellene være feilslåtte? Jeg skulle ønske at pasientenes beste ble den viktigste kompasskursen for at helsearbeidere skal føle at de gjør jobben sin på en ordentlig måte.

I dag kan det synes som om prosjekter, registreringer og tastetrykk er den eneste måten å bli vurdert som «flink» på i norsk helsevesen. Det er for galt dersom medisinsk og etiske tankegods som gjennom århundrer har vært grunnlaget for alt medisinsk arbeid og hele vårt helsevesen, blir feid til side av en økonomisk, tidsbesparende og kostnadseffektiv hverdag - i verdens rikeste land.

Kommentarer til og diskusjoner om innlegget finner du på blogg.tidsskriftet.no Vil du blogge, ta kontakt. 